\title{
Hasana Sharp in Conversation with Peter Gratton
}

\author{
Peter Gratton
}

Hasana Sharp's Spinoza and the Politics of Renaturalization comes at a perspicuous time. In recent years, there have been differing trajectories in Continental-inspired philosophy, which rarely overlapped: the first being the neo-Spinozisms of thinkers ranging from Althusser to Deleuze to Balibar to Montag, the second being new realisms and materialisms arguing against the supposed excesses of Continental anti-realisms. Sharp's book argues that the time for various forms of denaturalization have exhausted themselves through the excesses of social constructivism, and her task is to revisit Spinoza's philosophy as a means for rethinking the relation of mind and matter, political imagination, and praxis. Borrowing the term from Elizabeth Grosz, Sharp instead argues for "renaturalizing" the political, first by undoing the supposed sovereign mastery of the self, then by questioning any human distinction from nature, and finally by undermining traditional views of animality. Below, I ask her about what led her to this project and how she differentiates herself from others who have made the turn to materialism in recent years.

PETER GRATTON: Why don't we begin by asking you to situate your project. Many materialists return to a variety of figures, but you've turned instead to the supposed rationalism of Spinoza. Why? 
HASANA SHARP: Intellectual autobiographies probably all involve quite a bit of contingency. There weren't really considered reasons that led me to turn to Spinoza. Spinoza was simply part of my turning on to philosophy. Yet, it may help to note that Spinoza was part of a cluster of figures that prompted my addiction to philosophy, and the others were Louis Althusser, Michel Foucault, and Pierre Macherey. So, really, it makes perfect sense that you frame the question the way that you did. I had the good luck to be introduced to all of these figures by an exciting professor as an undergraduate (Warren Montag), who presented their views such that they seemed immediately relevant to my lived concerns with feminist, queer, and anti-racist politics. These figures all suggested to me new ways to think about freedom, transformation, and, in particular, the difficulties of struggle and change on a personal and collective level.

What Spinoza's rationalism offers, it seems to me, is a liberation from the moralism, frustration, and misanthropy that accompanies humanism (or, to use your language, idealism), according to which humanity is that special kind of being that can transcend its circumstances and act in contradiction to natural determination. I suspect that many young feminists, for example, find themselves deeply upset by concomitant experience of consciousness-raising and powerlessness. I found Spinoza's philosophy to be a rich therapeutic and intellectual resource for working through the resilience of damaging thought patterns, institutions, and discourses, and for trying to envision new forms of activism and critique. In short, I was enchanted in the last 18 months of my undergraduate career and have not been able to shake him since that fateful moment. I was lucky in my Master's program that I immediately found some co-conspirators among the students, and we forged a tight bond reading Spinoza, Marx, and Marxist philosophy. In fact, we dubbed ourselves "the materialist workshop" and morphed into the Society for Social and Political Philosophy, to which you have contributed many fine papers! 
PG: What is notable, however, is that you seem to resist the word "materialism" in favor of "renaturalization," perhaps since the central sections of the book focus on the power of ideas.

HS: Spinoza's philosophy certainly has rich affinities with materialism, and, as my answer above indicates, I have long been interested in materialism and what Althusser called "the subterranean current of the materialism of the encounter." In fact, as a prospective graduate student, I proposed a program of research into "non-teleological materialism," and I was keen to develop a materialist approach that did not treat non-human nature as inert, but as an active power (on this, I was also influenced by Etienne Balibar ${ }^{1}$ and Antonio Negri). I do think it is interesting and fruitful to think about Spinoza in terms of a peculiar kind of materialist tradition, given that he approaches thought, as Deleuze says, on the model of the body (Deleuze 18), and how important it is in his view that "consciousness" (a word that does not appear in Spinoza's text as such) does not, in Marx and Engels' terms, "determine life" (Marx and Engels 47).

But I did find, as a graduate student, that the idiom of materialism seriously restricted my audience. Those already initiated into French and Italian Marxism could understand what I meant, but to most others it was nonsensical to speak of Spinoza as a materialist. When I began working on Spinoza in the mid- to late-1990s, most Spinoza scholars were writing in the tradition of Leo Strauss or Jonathan Bennett and Ed Curley, and so the only people who could understand this idiom were very few, were in Australia, or were not in my discipline. Although the idea of "renaturalization" is also tightly bound to a tradition of Continental feminist theory, my hope is that it doesn't arouse the immediate skepticism that my earlier invocations of materialism did. On the one hand, it is a strange word, so perhaps readers are willing to let me stipulate a definition. Since many think they know what materialism means, they may not be as 
willing to let it do work that it does not typically do. On the other hand, naturalism is not at all a strange word, and neither is it counterintuitive to apply it to Spinoza's philosophy. In the end, the fact that I don't have to do the work to show how and why it might make sense to think about Spinoza as part of a materialist tradition may suggest that another terminology is more apt. These words are really lines in the sand, anyway, and perhaps it is a good idea to use one that is not as obviously partisan. Though, in a partisan spirit perhaps, I did want to ally myself with ecological philosophy and politics (especially the renegade ecofeminism of Haraway and Grosz - though I know the latter disowns that term), and the project of critically rethinking nature.

PG: How does one, then, account for "structures" of ideas repeatable across disparate geographies? In other words, if ideas are embedded in given contexts of affects, there is nevertheless a crystallization of them that seems ineradicable, such as racialist or patriarchal views. Isn't it also our task to denaturalize these ideas? Doesn't renaturalization risk "naturalizing" seemingly innocent ideas (such as vitality, power, and force) that have themselves played a role in the biopolitical?

HS: There are many different ways to account for ideas that seem ineradicable, and I don't mean to promote mine at the expense of others. Feminists like Gayle Rubin in her classic essay "The Traffic in Women," have done an amazing job of showing how, although patriarchy appears in most cultures across thousands of years, it takes such wildly different forms that there is no necessary expression of power relations between men and women. This is a powerful project of "denaturalization." Using anthropological research as well as a sophisticated theoretical toolbox, Rubin provides a great deal of counter-evidence for the claim that $\mathrm{X}$ or $\mathrm{Y}$ sex-gender system is 
natural, or inevitable. Likewise, philosophers and scientists have done a lot of work in the metaphysics of race to show conclusively that race is not a natural kind and, therefore, there is nothing necessary or inevitable about racial hierarchy. ${ }^{2}$ These sorts of analyses are indispensable.

Nevertheless, the argument of my book is that they pose certain risks without critical appraisal. There is a risk of reifying the nature-culture divide, representing culture as variable and nature as fixed and eternal. Thus, analysis can become stalled when one sees that patriarchy is human and not natural, and thus humans have to decide to change (a frequent conclusion of first year feminist theory students). My hope is that the idea of renaturalization is, in a way, even more de-naturalizing than denaturalization, if what denaturalization is supposed to do is unsettle what appears to be fixed. Why might this be true? Renaturalization, from within a Spinozist framework, shows that everything (finite) is dynamic and changeable. Nevertheless, change is not something that can be brought about by human will. Transformation must begin with work on webs of relations, on what I call "ecosystems" or networks of ideas and affects. This is entirely compatible with feminist and anti-racist analysis that emphasizes work on institutions, structures, linguistic habits, etc. Yet, I think an approach also armed with the renaturalist thesis poses less of a risk of dividing the "enlightened" from the ideologically duped. The renaturalist critics (you know, that massive group!) are in no way inoculated from the effects of the ideas they criticize. They should not see themselves and others as failures insofar as they cannot embody the feminist or anti-racist critique. Rather, our own feelings of misogyny and racism are indices of the power that these ideas exert in our milieus, a sign of how much of the fight still remains, and of how many more allies are needed to feel and live differently.

I haven't really addressed your concerns about my embrace of the language of vitalism and natural science. Certainly, no language is innocent, and no theoretical apparatus is immune 
to cooptation by oppressive forces. I use this language strategically to counter my bete noire, the idiom of humanism: consciousness, personality, rights, choice, will, etc. It is certainly possible that the effects of my alternative could be worse than humanism, and we would then be stuck with what I take to be an empirically false and ethically problematic model of what kinds of beings we are. My hope is that it can have its place — in the court of law, for example — but that it can be critically engaged by a more naturalistic language and a framework that does not sustain what I continue to think of as a destructive fantasy of human exceptionalism.

PG: Your book comes in the wake of a number of new readings of Spinoza, as I note above. Is there something you think has been missing, say, from Deleuze or Negri's accounts?

HS: Deleuze and Negri_-among others, like Balibar, Del Luchese, and Montag — offer creative and inspiring interpretations of Spinoza. I see my own book as closest in spirit perhaps to the work of Gatens and Lloyd (and, in spirit, if not in content, with Butler) who, in addition to providing an interpretation of his system, bring Spinoza into much more explicit conversation with contemporary concerns, especially in political and feminist theory. The difficulty with using Spinoza to discuss contemporary issues is that, although we use many of the words he useshuman, reason, mind, power-he means something very different than we usually do. Yet, of course, this is what I take to be the advantage of his system. He reframes these terms and embeds them in a view of reality that is quite at odds with the dominant discourse in political theory. My own thesis of renaturalization draws a great deal upon the resources of a number of creative "new readings" (i.e., post 1968)—-some of which are really quite difficult — and puts them to work on what I identify as pressing issues. My hope is that my account makes Spinoza's rather 
difficult philosophy accessible and engaging by virtue of linking it to concerns that weigh heavily on many of us today. I hope that my book illuminates aspects of Spinoza's views for my fellow Spinoza lovers, but I also hope it shows those not yet excited about him how his strange world might open up new vistas for folks interested in feminism, anti-racism, and ecopolitics (among others).

\section{Notes}

${ }^{1}$ See Balibar, 23-25.

${ }^{2}$ For a good overview, see Taylor.

\section{Works Cited}

Althusser, Louis. "The Underground Current of the Materialism of the Encounter," in Philosophy of the Encounter: Late Writings, 1978-1987. Trans. G.M. Goshgarian. London: Verso, 2006.

Balibar, Etienne. The Philosophy of Marx. Trans. C. Turner. London: Verso, 1995.

Deleuze, Gilles. Spinoza: Practical Philosophy. Trans. R. Hurley. San Francisco: City Lights Books, 1970.

Engels, Friedrich and Karl Marx. The German Ideology. Ed. C. Arthur. New York: International Publishers, 1970.

Negri, Antonio. "Notes on the Evolution of the Later Thought of Louis Althusser," in Postmodern Materialism and the Future of Marxist Theory: Essays in the Althusserian Tradition. Ed. A. Callari and D.F. Ruccio. Hanover: Wesleyan University Press, 1996.

Rubin, Gayle. "The Traffic in Women: Notes on the 'Political Economy' of Sex," in Toward an Anthropology of Women. Ed. R. Reiter. New York: Monthly Review Press, 1975.

Taylor, Paul. Race: A Philosophical Introduction. Cambridge: Polity Press, 2003. 